\title{
Occasional viewpoint
}

\section{What has happened to the cathartic colon?}

\begin{abstract}
'The prolonged and habitual use of laxatives is unhealthy' ${ }^{1}$ Confusion! The terms cathartic colon, laxative abuse, and use of laxatives clearly describe three different conditions. Use and abuse of laxatives could only be equated if every prolonged or habitual use, or both, were abuse. But this is not so. There is a considerable lobby against laxatives, which contrasts with the frequency by which they are taken as self medication. One of the bugbears warned against is 'the cathartic colon'. This condition is cited in most medical textbooks. Yet, despite seeing many patients who have taken laxatives for many years, the author has never seen a case of cathartic colon. The same holds true for colleagues from other European countries. Therefore an analysis of the published cases of cathartic colon seemed interesting. The results shall be presented against the background of what is known about damage by laxatives to the colon and about laxative misuse.
\end{abstract}

\section{Evidence that currently used laxatives damage the colon}

Probably, the most frequently cited experimental study was done in mice with oral and intraperitoneal application of a senna syrup. ${ }^{2}$ Unfortunately, details of the methodology (composition of the syrup, dose, duration of treatment) as well as data are lacking. A time dependent 'degeneration' of nerve fibres is quoted, which could be seen after silver staining. In contrast, no changes were found in mice and rats treated with sennosides orally using the electron microscope or immunohistochemical staining. ${ }^{3-5}$ It has been speculated that the senna syrup mentioned above might have contained free (that is, not glycosylated) anthraquinones. These are absorbed in the small intestine and might be systemically toxic.

Axonal damage was found in constipated patients who had taken a variety of laxatives. ${ }^{6}{ }^{7}$ In patients with slow colonic transit abnormalities of the nerve plexus and a reduced or totally lacking reaction of the enteric nerves with a neurofilament specific antibody was observed. ${ }^{89}$

When we treated rats with different doses of sennosides and sodium picosulphate a decrease in colonic tissue concentrations of vasoactive intestinal peptide and somatostatin was found after high doses of sennosides whereas concentrations of substance $P$ were unchanged..$^{10}$ In contrast, patients with slow colonic transit had decreased rectal mucosal substance P concentrations, but vasoactive intestinal peptide and somatostatin were normal. ${ }^{11}$ Hence, the changes in patients were probably not the result of prolonged laxative intake. Another study compared the morphology of the autonomous nervous system of constipated patients taking anthraquinones (aloe) with that of an appropriate control group of constipated patients without laxative intake. These authors did not find any relevant differences with respect to the electron microscopic appearance. ${ }^{12}$

In summary, morphological damage of the autonomous nervous system of the colon by sennosides in glycosidic binding or by bisacodyl and related compounds in clinically relevant dosage has not been shown either in experimental animals or in humans. The abnormalities seen in patients are probably not a consequence of laxative intake, rather they represent pre-existent changes of unknown aetiology, which lead to slow colonic transit, which in turn caused the patient to take a laxative.

\section{Laxative abuse}

Besides diuretics, laxatives are among the drugs with a comparatively high rate of abuse, particularly in patients with anorexia nervosa, bulimia, and Münchhausen syndrome. The frequency of laxative induced diarrhoea among 200 patients with diarrhoea was $3 \cdot 5 \% .{ }^{13}$ In another study in 27 patients with diarrhoea in whom a previous diagnostic procedure had not revealed a cause, laxative intake was eventually uncovered in a quarter. ${ }^{14}$

The literature on case reports of hidden laxative use comprises more than 70 publications with 240 cases. ${ }^{15}$ With few exceptions, patients were hospitalised for diarrhoea of unknown origin, weight loss, abdominal pain, or muscular weakness (due to hypokalaemia). Laxative intake was usually only admitted after confrontation with a positive finding at a locker search or with a positive assay in urine. The reported doses are therefore to be interpreted with caution. They are scattered over a wide range which goes up to 200 doses per day. The preferred drugs are phenolphthalein, plant extracts containing anthraquinones, and bisacodyl. More than $95 \%$ of the patients were female. No case of cathartic colon was reported among them.

\section{Case reports of cathartic colon}

The diagnosis of cathartic colon is based on a barium enema. The original publication of Heilbrun mentions the following characteristics: loss of haustration, pseudostrictures (that is, variable sandglass formed spasms), dilated lumen, dilated terminal ileum, and gaping of the ileocaecal valve. If only part of the colon is affected, there is a predilection of the right hemicolon. ${ }^{16}$ Other case reports were identified by a Medline search and by checking the reference lists of the literature regarding laxative intake available to the author. A total of 41 alleged cases of cathartic colon could be identified from 18 papers. ${ }^{16-33}$ On the published $x$ ray films the presence or absence of the characteristics of the cathartic colon was noted. In a few cases, detailed verbal description of the findings was also accepted if the barium enema was not reproduced or if the (usually photocopied) photograph was technically insufficient. Three of nine cases of Heilbrun were also accepted though not confirmed by a published $x$ ray or a detailed description because of the particular awareness and experience of this author and the impeccable presentation of the other cases of his series. The presence or absence of a dilated terminal ileum and gaping of the ileocaecal valve could not be evaluated in 
some cases because the terminal ileum was not filled with contrast. The minimal requirements to accept the diagnosis of cathartic colon was the loss of haustration in the right hemicolon or entire colon. In 24 of 39 cases pseudostrictures were seen, in 22 a dilated terminal ileum, and in 16 gaping of the ileocaecal valve. Two of the published cases did not meet the mimimal requirement of loss of colonic haustration and were excluded. ${ }^{29} 31$

Loss of haustration as well as changes of the ileum are not specific for the cathartic colon as they also occur in longstanding ulcerative colitis. In contrast, the variable sandglass formed spasms, called pseudostrictures, are not known with any other condition. Hence, it would seem logical that only those 24 cases with reported pseudostrictures were considered as confirmed cases of cathartic colon. On the other hand, an $x$ ray without pseudostrictures does not prove their absence because they are inconstant and may wax and wane. ${ }^{23}$ In addition, ulcerative colitis would have been unlikely to be associated with constipation and to lead to laxative ingestion. Finally, the profile of laxatives consumed is similar in patients with and without pseudostrictures, respectively (see later). Hence, the conclusions are similar whether the cases without pseudostrictures are excluded or not.

\section{Characteristics of the patients with cathartic colon} All patients were female with an age range of 28 to 85 years (mean 55). The start of laxative intake was given in 35 cases and ranged between 1910 to 'before 1960 '. ${ }^{19}{ }^{26}$ The period of intake ranged from more than 10 to 70 years (mean >26). Most of the cases were published in the 'sixties whereas most laxative abuses were published later (Fig 1). The reason for intake was stated in two thirds of cases. Usually, the amount taken was in the recommended range, and the patients mentioned the laxative intake spontaneously.

\section{Laxatives used by patients with cathartic colon}

No case of cathartic colon has been published in which laxative intake started around 1960 or later. This favours an out of fashion laxative as the cause of cathartic colon. In 27 cases when information about the types of laxatives was available, the most striking finding is that podophyllin was used by 22 of the patients (Fig 2), which makes it the most promising candidate. In view of the usually very long periods of laxative intake, namely several decades, it is easily possible that also the rest of the patients had taken podophyllin for some time without recalling or mentioning it.

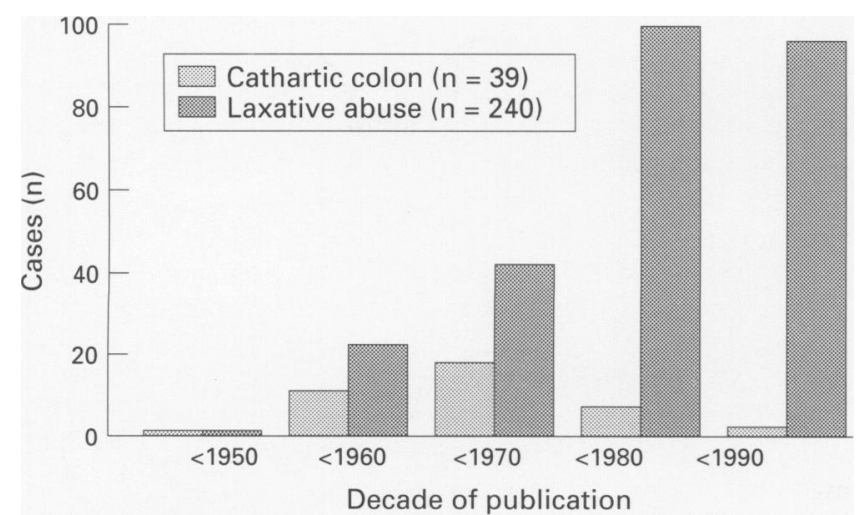

Figure 1: Numbers of published cases of cathartic colon and laxative abuse, respectively, in the five decades from 1941 to 1990. Laxative abuse data from reference 15.

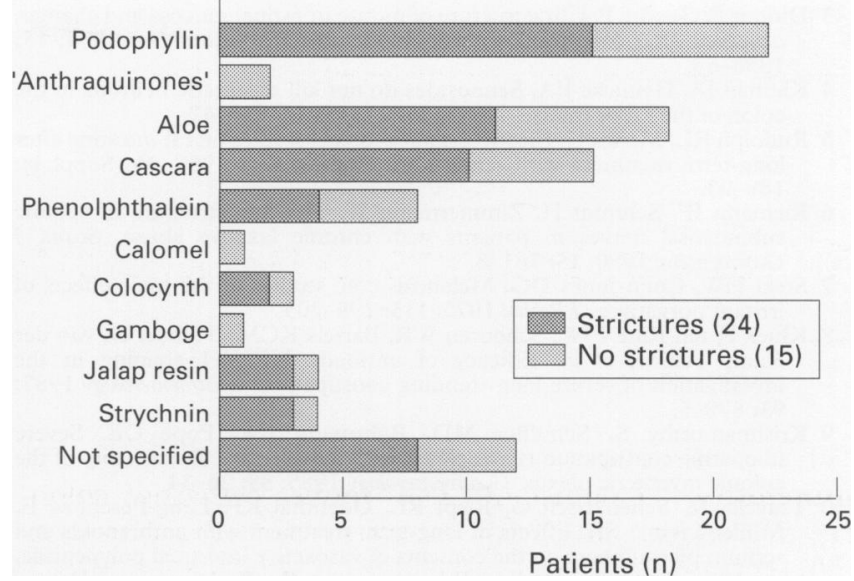

Figure 2: Laxatives used by the patients with cathartic colon. The distribution is similar whether pseudostrictures are visible or not.

\section{Podophyllin}

Podophyllin resin is obtained from the May apple (Podophyllum peltatum) and contains several chemicals among which podophyllotoxin is probably most relevant. ${ }^{34}$ It acts as a metaphase poison and resembles colchicine and vinblastine with respect to both structure and effect. Podophyllotoxin is still used in dermatology to treat genital warts. When given systemically it is a potent neurotoxin. The acute intoxication lasts for several days. It is characterised by a comatose state, which may be accompanied by paralytic ileus and bone marrow depression. Subsequently, a sensimotor neuropathy develops over several days and persists for at least months to years. Intoxication with podophyllin occurred when the solution for topical application was used intravaginally ${ }^{35}$ or was ingested accidentally. ${ }^{37}$ Other cases were reported from Hong Kong where podophyllin containing broths are used in traditional Chinese medicine. ${ }^{38}$ Finally, podophyllin as part of a laxative caused intoxication in a young women with laxative abuse for intended weight reduction (such a laxative was still marketed 10 years ago in Australia). ${ }^{39}$ Unfortunately, no light or electron microscopic studies of the enteric nervous system in cathartic colon are available. It seems attractive, however, that longterm intake of podophyllin containing laxatives in 'therapeutic doses' could have induced a neuropathy of the (ileo)colonic enteric nervous system. No information could be obtained as to how well podophyllin is absorbed from the gastrointestinal tract and whether its laxative action requires systemic absorption or is local via the colonic mucosa.

\section{Conclusion}

The cathartic colon is obviously a historical entity unlikely to be observed nowadays. It was probably caused by podophyllin but is not induced by the currently available laxatives, even if they are used over long periods or in excessive doses. Cathartic colon must not be confused with laxative abuse and should probably not be mentioned any more in non-specialist textbooks.

Abteilung für Innere Medizin,

STEFAN MÜLLER-LISSNER

Krankenhaus Weißensee Schönstr 87-91,

D-13086 Berlin, Germany

1 Brunton LL. Agents affecting gastrointestinal water flux and motility, digestants, and bile acids. In: Goodman Gilman A, Rall TW, Nies AS, Taylor P, eds. The pharmacological basis of therapeutics, 8th ed. New York: Pergamon Press, 1990: 914-32.

2 Smith B. Effect of irritant purgatives on the myenteric plexus in man and the mouse. Gut 1969; 9: 139-43. 
3 Dufour P, Gendre P. Ultrastructure of mouse intestinal mucosa and changes observed after long-term anthraquinone administration. Gut 1984; 15: 1358-63.

4 Kiernan JA, Heinicke EA. Sennosides do not kill myenteric neurons in the colon of the rat or mouse. Neuroscience 1989; 30: 837-42.

5 Rudolph RL, Mengs U. Electron microscopical studies on rat intestine afte long-term treatment with sennosides. Pharmacology 1988; 36 (Suppl 1) 188-93.

6 Riemann JF, Schmidt H, Zimmermann W. The fine structure of colonic submucosal nerves in patients with chronic laxative abuse. Scand $f$ Gastroenterol 1980; 15: 761-8.

7 Steer HW, Colin-Jones DG. Melanosis coli: studies of the toxic effects of irritant purgatives. $\mathcal{F}$ Pathol 1975; 115: 199-205.

8 Klück P, ten Kate FIW, Schouten WR, Bartels KCM, Tibboel D, van der Kamp AWM, et al. Efficacy of antibody NF2F11 staining in the investigation of severe long-standing constipation. Gastroenterology 1987; investigation $872-5$.

9 Krishnamurthy S, Schuffler MD, Rohrmann CA, Pope CE. Severe idiopathic constipation is associated with a distinctive abnormality of the colonic myenteric plexus. Gastroenterology 1985; 88: 26-34.

10 Tzavella K, Schenkirsch G, Riepl RL, Odenthal KP, Leng-Peschlow E, Müller-Lissner SA. Effects of long-term treatment with anthranoids and sodium picosulphate on the contents of vasoactive intestinal polypeptide somatostatin, and substance $P$ in rat colon. Eur $f$ Gastroenterol Hepato 1995; 7: 13-20

11 Tzavella K, Riepl RL, Müller-Lissner SA. Decreased substance P levels in rectal biopsies from patients with slow transit constipation. Gastroenterology 1994; 106: A580.

12 Riecken EO, Zeitz M, Emde C, Hopert R, Witzel L, Hintze R, et al. The effect of an anthraquinone laxative on colonic nerve tissue: a controlled trial in constipated women. $Z$ Gastroenterol $1990 ; 28: 660-4$

13 Bytzer P, Stokholm M, Andersen I, Klitgaard NA, Schaffalitzky de Muckadell OB. Prevalence of surreptitious laxative abuse in patients with diarrhoea of uncertain origin: a cost benefit analysis of a screening procedure. Gut 1989; 30: 1379-84

14 Read NW, Krejs GJ, Read MG. Chronic diarrhea of unknown origin. Gastroenterology 1980; 78: 264-71.

15 Leng-Peschlow E. Senna and its rational use. Pharmacology 1992; 44 (suppl 1)

16 Heilbrun N. Roentgen evidence suggesting enterocolitis associated with prolonged cathartic abuse. Radiology 1943; 41: 486-91.

17 Avery Jones F. Cathartic colon. Proc R Soc Med 1967; 60: 503-5.

18 Campbell WL. Cathartic colon. Reversibility of roentgen changes. Dis Colon Rectum 1983; 26: 445-8.
19 Conte M, Frumusan P, Goiffon B, Fouet P, Bodin F, le Guillant F, et al. Iléo-colite grave, avec atteinte rénale, par prise prolongée de laxatives. Arch Franc Mal App Dig 1967; 56: 703-12.

20 Cope CL. A case of purgative addiction. BM7 1966; 1: 1344-8.

21 Diller WF. Röntgenologische Aspekte des "Abführmittelcolons". Dtsch Med Wochenschr 1965; 90: 478-83.

22 Geboes K, Bossaert H. Cathartic colon - two case reports. Am $\mathcal{f}$ Proctol 1980; 31: 21-4.

23 Heilbrun N, Bernstein C. Roentgen abnormalities of the large and small intestine associated with prolonged carthagic ingestion. Radiology 1995 65: 549-56.

24 Jewell FC, Kline JR. The purged colon. Radiology 1954; 62: 368-70.

25 Kim SK, Gerle RD, Rozanski R. Cathartic colitis. Am $f$ Roentgenol 1978; 131: $1079-81$

26 Lemaitre G, L'Herminé $C$, Decoulx $M$, Houcke $M$, Linquette $M$. Aspect radiologique des colites chroniques par abus de laxatifs a propos de quatre radiologique des colites chroniques par abus de

27 Marshak RK, Gerson A. Cathartic colon. Am f Dig Dis 1960; 5: 724-7.

28 Plum GE, Weber HM, Sauer WG. Prolonged cathartic abuse resulting in roentgen evidence suggestive of enterocolitis. Am $\mathcal{F}$ Roentgenol 1960; 83: 919-25.

29 Plumley PF. Radical surgery in the treatment of carthatic colon. Proc $R$ Soc Med 1973; 66: 243-4.

30 Rawson MD. Cathartic colon. Lancet 1966; i: 1121-4.

31 Schmidt H, Riemann JF, Rödl W. Megakolon nach langiährigem Laxantienabusus. Med Klin Prax 1983; 78: 62, 64, 76.

32 Urso FP, Urso MJ, Lee CH. The cathartic colon: pathological findings and radiological/pathological correlation. Radiology 1975; 116: 557-60.

33 Ziter FMH. Cathartic colon. N Engl Med f 1967; 67: 546-9.

34 Beutner KR, van Krogh G. Current status of podophyllotoxin for the treatment of genital warts. Semin Dermatol 1990; 2: 148-51.

35 Filley CM, Graff-Redford NR, Lacy JR, Heitner MA, Earnest MP. Neurologic manifestation of podophyllin toxicity. Neurology 1982; 32 308-11.

36 Pottier Y, Mullier JP, Huysman E, Paulet P. Ileus paralytique secondaire une intoxication à la podophylline. Acta Gastro-enterol Belg 1988; 52 23-7.

37 Chapon F, Dupuy B, Gosset S, Carjuzaa A, Berthelin C, Viader F, et al. Intoxication accidentelle à la podophylline. Rev Neurol 1991; 147: 240-3.

$38 \mathrm{Ng}$ THK, Chan YW, Yu YL, Chang CM, Ho HC, Leung SY, et al. Encephalopathy and neuropathy following ingestion of a Chinese herbal broth containing podophyllin. F Neurol Sci 1991; 101: 107-13.

39 Dobb GJ, Edis RH. Coma and neuropathy after ingestion of herbal laxative containing podophyllin. Med $\Im$ Austr 1984; 140: 495-6. 